\title{
Effect of Planting Season on Yield of Sweetpotato Cultivars ${ }^{1}$
}

\author{
José Badillo-Feliciano²
}

\begin{abstract}
Nine sweetpotato cultivars were evaluated in six bimonthly plantings on a Coto clay (Oxisol) to determine effect of planting season on yields. All crops were harvested 5 months after planting. The tests included the white-fleshed cultivars Miguela, Mina, Chardón, Ponceña, and Blanquita, and the yellow-fleshed Gem, Cobre, L 963-3, and R 59-36. Maximum yields of roots, either white- or yellow-fleshed, were obtained from November 1973 plantings. Yields from March or May 1974 plantings generally were low.

Of the white-fleshed cultivars, Miguela and Mina were consistently high yielders. Peak yields from cultivars Ponceña and Blanquita were obtained from November 1973 plantings and low yields from July 1973 and May 1974 plantings. Chardón made poor yields throughout the year.

Gem produced high yields throughout the year and seemed to be less photosensitive than the other three yellow-fleshed cultivars. Cultivar $\mathrm{R}$ 59-36 seemed most affected by day-length with peak yield from the November planting and the lowest yield in the May 1974 plantings. Cultivar L 963-3 made good yields throughout the year. Cobre made lowest yield from July 1973 planting and peak yield was obtained from November planting.
\end{abstract}

\section{INTRODUCTION}

Sweetpotatoes (Ipomoea batatas (L.) (Lam.)) are a staple in the Puerto Rican diet. They also are used widely as food on other islands of the Caribbean, in Latin America, in the Southern United States, and in other parts of the world. Sweetpotatoes are estimated to produce 400 kcals of energy per pound ${ }^{3}$. They also are used commonly as animal feed and offer considerable potential for industrial purposes such as in the manufacture of starch and dextrin. During fiscal year 1973-74, 1667.6 tons $(36,753 \mathrm{cwt})$ of sweetpotatoes valued at $\$ 515,232$, were sold in the seven principal markets of the Island, an increase of some $\$ 207,935$ over

${ }^{1}$ Manuscript submitted to Editorial Board January 17, 1975.

${ }^{2}$ Associate Agronomist, Agricultural Experiment Station, University of Puerto Rico, Mayagüez Campus, Río Piedras, Puerto Rico. Appreciation is extended to Dr. M. A. LugoLópez for reviewing the manuscript and for his valuable suggestions.

${ }^{3}$ Gurney, J. M., Nutritional considerations regarding staples. Paper presented at the Caribbean Food Crops Society Meeting, Jamaica, 1974. 
the previous year. Market acceptance and steady increases in prices registered suggest that sweetpotatoes offer good potential in a program of intensive agricultural development as a source of food both for local consumption and for export. This crop can be grown throughout the year but is planted mainly during the fall (September to October) and harvested during the beginning and middle of the following dry season. Sweetpotatoes grow in nearly all parts of the Island, even in unfertile, droughty, sandy soils. They grow exceptionally well on sandy loams and in open, loose clayey soils. Cultivars differ considerably in their adaptability to climatic, edaphic, and other conditions prevailing in different areas of the Island.

Moscoso ${ }^{4}$ reported preliminary results of experiments conducted during 1954 at nine locations in Puerto Rico during two planting seasons, September to December and January to June. The best yields were obtained in September to December plantings, the short-day season. The yellow-fleshed cultivars tested included Canela, Rico, L 138-S, L 224, L 225, UPR 3 and L 240-7. Landrau et al. ${ }^{5}$ also observed the influence of time of planting on yields. UPR 3 , a yellow-fleshed cultivar which is no longer planted commercially, produced higher yields when planted from October to February and lower yields when planted from March to July.

Because of the economic potential of this root crop, this new study was conducted on the effect of planting season on yields of the more promising commercially available varieties. Nine outstanding whiteand yellow-fleshed sweetpotato cultivars, obtained from more recent selection and variety evaluation trials, were included.

\section{MATERIALS AND METHODS}

All experiments were conducted on a Coto soil (Typic Haplorthox, clayey, kaolinitic, isohyperthermic) at the Isabela Agricultural Experiment Substation farm in northwestern Puerto Rico. The nine cultivars were tested in six bimonthly plantings, starting in July 1973. The white-fleshed cultivars Miguela, Mina, Chardón, Ponceña, and Blanquita were included in the tests along with yellow-fleshed cultivars Gem, Cobre, R 59-36, and L 963-3. The white- and yellow-fleshed cultivars were tested in separate adjacent trials.

Experimental plots consisted of four rows $1.07 \mathrm{~m}(3.5 \mathrm{ft})$ apart and 5.49 $\mathrm{m}$ (18.0 ft) long, bordered by a blank row with $1.52 \mathrm{~m}(5.0 \mathrm{ft})$ alleys between plots.

\footnotetext{
'Moscoso, C. G., El cultivo de la batata en Puerto Rico, Est. Exp. Agr. Univ. P.R. Bol. $126,1955$.

${ }^{5}$ Landrau, P., Jr., and Samuels, G., The effect of fertilizers on the yield and quality of sweetpotatoes, J. Agr. Univ. P.R., 35(2): 71-87, 1951.
} 
Treatments followed a randomized block design with six replications. Cultivars were propagated from vine cuttings of approximately $7.09 \mathrm{~cm}$ (18 in) long planted on a raised bed. In a single operation the beds were ridged by two double-moldboard plows with a full sweep attached behind. The full sweep opened the beds into a 1.18 to $1.57 \mathrm{~cm}$ (3.0 to 4.0 in) deep mini-furrow. The cuttings were placed into these mini-furrows and covered with soil using hand labor. Diphenamid $50 \mathrm{~W}^{6}$ was applied at a rate of $15.69 \mathrm{~kg} / \mathrm{ha}(14.0 \mathrm{lb} / \mathrm{acre})$ as a preemergent herbicide. Two weeks after planting, the growing vines received an application of 1345 $\mathrm{kg} / \mathrm{ha}$ (1200 lb/acre) of 6-6-12 fertilizer. Cultivation was mechanical as long as vine size permitted after which hand cultivation was used. Insects were controlled with biweekly applications of $473 \mathrm{~cm}^{3}(1 \mathrm{pt})$ of Diazinon AG-500 in 378.5 l (100 gal) of water per acre. When rainfall was not enough for sustained growth, supplemental irrigation was applied. When the crop was 5 months old, the roots were harvested using a potato digger.

\section{RESULTS AND DISCUSSION}

\section{WHITE-FIESHED CULTIVARS}

Consumers in Puerto Rico have shown a marked preference for white-fleshed sweetpotatoes as compared to yellow-fleshed varieties, although the latter are recommended for their high carotene (vitamin A) content. Yield data of white-fleshed cultivars are presented in table 1. Crop yields were measured in terms of marketable roots. The relationship between yield and planting dates is shown in figure 1 .

\section{Varieties vs. Planting time}

Miguela. Peak yields (38.7 tons/ha) of this cultivar were obtained when planted in November 1973. Yields were 19.1 and 20.7 tons/ha higher than those obtained from the March and the May 1974 plantings, respectively. The January 1974 planting produced 29.3 tons/ha, or 1.6 tons/ha more than were obtained from the July 1973 plantings. The September planting yielded 3.8 and 2.2 tons/ha more than both the July 1973 and January 1974 plantings, respectively. It was evidently more profitable to plant this cultivar in September than to delay the planting until January.

Chardon. Although this cultivar was a low yielder throughout the year, its peak production (19.1 tons/ha) was obtained from the November 1973

\footnotetext{
${ }^{6}$ Trade names are used in this publication solely for the purpose of providing specific information. Mention of a trade name does not constitute a guarantee or warranty of equipment or materials by the Agricultural Experiment Station of the University of Puerto Rico or an endorsement over other equipment or materials not mentioned.
} 
planting. The yields obtained from the March and the May 1974 plantings were higher than those from the July and the September 1973 plantings.

Mina. This cultivar, when planted September 1973, produced 5.2 and 12.6 tons/ha more than when planted January 1974 and September 1973, respectively. The peak yield (36.8 tons/ha) was obtained from the November 1973 planting. Yields from the July planting were 1.6 and 8.5 tons/ha higher than those from the July 1973 and March 1974 plantings, respectively. Yields from the May planting were the lowest. This cultivar produced acceptable yields when planted from July to March.

Ponceña. Ponceña produced 28.8 tons/ha when planted in September 1973; that is, 6.6 and 6.8 tons/ha more than the yields obtained from the July 1973 and January 1974 plantings, respectively. Peak yields (37.8

TABLE 1.-Yield of white-fleshed sweetpotato cultivars planted at six different dates

\begin{tabular}{lrrrrrr}
\hline \multirow{2}{*}{ Cultivar } & \multicolumn{5}{c}{ Yields at indicated date of planting (tons/ha) $^{\prime}$} \\
\cline { 2 - 7 } & July/73 & Sept./73 & Nov. $/ 73$ & Jan. $/ 74$ & Mar. $/ 74$ & May/74 \\
\hline Miguela & $27.7 \mathrm{a}$ & $31.5 \mathrm{a}$ & $38.3 \mathrm{a}$ & $29.3 \mathrm{ac}$ & $19.2 \mathrm{a}$ & $17.6 \mathrm{a}$ \\
Chardón & $9.5 \mathrm{c}$ & $13.4 \mathrm{c}$ & $19.1 \mathrm{~b}$ & $10.9 \mathrm{~b}$ & $17.4 \mathrm{a}$ & $15.0 \mathrm{~b}$ \\
Mina & $22.5 \mathrm{~b}$ & $35.1 \mathrm{a}$ & $36.8 \mathrm{a}$ & $29.9 \mathrm{ac}$ & $20.9 \mathrm{a}$ & $14.0 \mathrm{~b}$ \\
Ponceña & $22.2 \mathrm{~b}$ & $28.8 \mathrm{a}$ & $37.8 \mathrm{a}$ & $22.0 \mathrm{a}$ & $14.6 \mathrm{a}$ & $16.7 \mathrm{a}$ \\
Blanquita & $10.4 \mathrm{c}$ & $20.4 \mathrm{~b}$ & $34.6 \mathrm{a}$ & $23.9 \mathrm{ac}$ & $19.9 \mathrm{a}$ & $11.9 \mathrm{~b}$ \\
\hline
\end{tabular}

${ }^{1}$ Means in any column followed by the same letter are not significantly different at the 0.05 probability level.

tons/ha) were obtained from the November 1973 planting. Yields from the March and May 1973 plantings were relatively low.

Blanquita. This cultivar, planted in January 1974, produced 23.9 tons/ha, or 3.5 and 4.0 tons/ha higher than the yields obtained from the September 1973 and March 1974 plantings, respectively. Peak production (34.6 tons/ha) was obtained from the November 1973 planting. Yields from the July 1973 and the May 1974 plantings were the lowest.

\section{Overall Seasonal Effect}

The best yield was obtained when sweetpotatoes were planted in November 1973; the lowest, when the crop was planted either in March or in May. However, when planted either in September 1973 or January 1974, yields were relatively high.

The performance of cultivars Miguela and Mina indicates that they are consistently good yielders when planted throughout the year. A consistent reduction in yields was observed on the March 1974 and May 1974 plantings, however, Ponceña yielded the highest in the November 
plantings with a slight decrease in the September 1973 and January 1974 plantings. Blanquita and Ponceña followed a more or less similar yield pattern, while Chardón was generally the poorest yielder of all cultivars.

\section{Evaluation by Crops}

July 1973 Planting. Miguela produced significantly higher yields than those obtained from the Chardón, Mina, Ponceña, and Blanquita cultivars. There were no significant differences between the mean yields

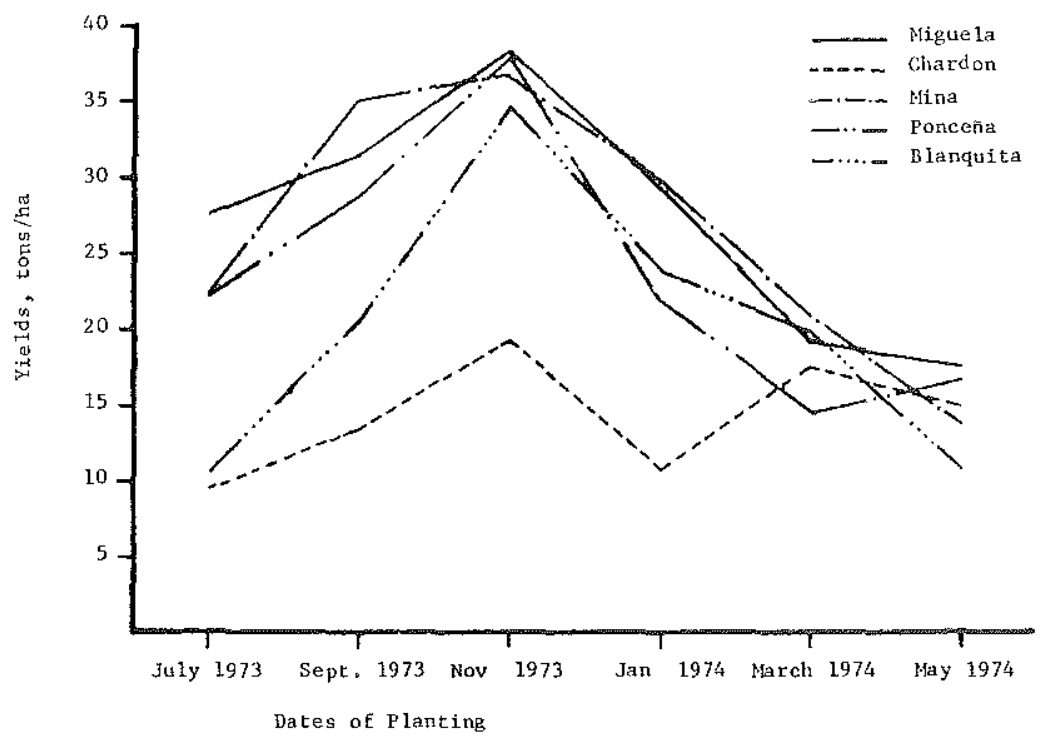

Fic. 1. Relationship between dates of planting and yield of white-fleshed sweetpotatoes.

of Mina and Ponceña cultivars. Mina and Ponceña produced significantly higher yields than Blanquita and Chardón, however. There were no significant differences between the yields of the latter two cultivars.

September 1973 Planting. There were no significant differences between yield means of Mina, Miguela, and Ponceña cultivars. These three cultivars produced significantly higher yields than Blanquita and Chardón, and Blanquita outyielded Chardón.

November 1973 Planting. There were no significant differences between the mean yields of Miguela, Ponceña, Mina, and Blanquita, but all these cultivars outyielded Chardón.

January 1974 Planting. There were no significant differences between the mean yields of the Mina, Miguela, and Blanquita cultivars. Yields from Mina, Miguela, Blanquita, and Ponceña were significantly higher 
than those obtained from Chardón, and Mina and Miguela produced significantly higher yields than Ponceña.

March 1974 Planting. There were no significant differences between mean yields at this planting date, and yields from most of the cultivars were drastically reduced in relation to those made by the previous four crops.

May 1974 Planting. There were no significant differences between mean yields of Chardón, Mina and Blanquita although Miguela and Ponceña outyielded Blanquita.

All crops. Analysis of mean pooled yields from the six crops show that Miguela and Mina averaged 27.3 and 26.5 tons/ha/crop, respectively. There were no significant differences between their mean yields although

TABLE 2,-Effect of date of planting on percentage of nonmarketable roots produced by five white-fleshed cultivars

\begin{tabular}{|c|c|c|c|c|c|c|}
\hline \multirow[b]{2}{*}{ Cultivar } & \multicolumn{6}{|c|}{ Percent of nonmarketable roots at indicated date of planting } \\
\hline & $\begin{array}{l}\text { July } \\
1973\end{array}$ & $\begin{array}{l}\text { Sept. } \\
1973\end{array}$ & $\begin{array}{l}\text { Nov. } \\
1973\end{array}$ & $\begin{array}{l}\text { Jan. } \\
1974\end{array}$ & $\begin{array}{c}\text { March } \\
1974\end{array}$ & $\begin{array}{l}\text { May } \\
1974\end{array}$ \\
\hline Miguela & $3.62 \mathrm{a}^{1}$ & $2.68 \mathrm{a}$ & $2.90 \mathrm{a}$ & $3.07 \mathrm{c}$ & $3.40 \mathrm{c}$ & $9.46 \mathrm{a}$ \\
\hline Chardón & $12.69 \mathrm{~b}$ & $7.49 \mathrm{bc}$ & $7.81 \mathrm{~b}$ & $11.02 \mathrm{a}$ & $7.65 \mathrm{~b}$ & $7.50 \mathrm{a}$ \\
\hline Mina & $7.22 \mathrm{a}$ & $4.42 \mathrm{c}$ & $5.45 \mathrm{~b}$ & $5.95 \mathrm{bc}$ & $10.25 \mathrm{ab}$ & $8.45 \mathrm{a}$ \\
\hline Ponceña & $3.48 \mathrm{a}$ & $2.07 \mathrm{a}$ & $1.92 \mathrm{a}$ & $3.91 \mathrm{c}$ & $9.00 \mathrm{~b}$ & $5.09 \mathrm{a}$ \\
\hline Blanquita & $15.32 \mathrm{~b}$ & $7,42 \mathrm{bc}$ & $3.25 \mathrm{a}$ & $9.07 \mathrm{ab}$ & $12.88 \mathrm{ab}$ & $8.65 \mathrm{a}$ \\
\hline
\end{tabular}

${ }^{1}$ Means in any column followed by the same letter are not significantly different at the 0.05 probability level.

mean yields from both cultivars were significantly higher than those of Chardón, Ponceña, and Blanquita. Ponceña, as an average, yielded 23.7 tons/ha. This was higher than the mean yields obtained from the Chardón and Blanquita cultivars. The Blanquita cultivar outyielded Chardón by an average of 6.0 tons/ha/crop. Chardón was the lowest yielder.

\section{Nonmarketable Yields}

Table 2 shows that the percentage of nonmarketable roots did not follow a specific trend in relation to planting dates. There were significant differences in the amount of nonmarketable roots among cultivars within the different planting dates, however. Irrespective of planting dates, all crops produced above $90 \%$ marketable roots, except Chardón and Blanquita. Chardón yielded 87.3 and $89.0 \%$ in the July 1973 and January 1974 crops, respectively. Blanquita yielded 84.7 and $87.1 \%$ in the July 1973 and March 1974 crops, respectively. 
Yellow-fleshed sweetpotatoes are a good source of energy and are known particularly for their high content of vitamin A. They offer considerable potential for processing and canning for export purposes. Yield data of the yellow-fleshed cultivars are presented in table 3. Crop yields were measured as total weight of roots produced. The relationships between yield and planting dates are shown in figure 2 .

\section{Varieties vs. Planting Time}

Gem. This cultivar was a high yielder throughout the year. It appeared to be less photosensitive than the other three yellow-fleshed cultivars. The July 1973 and the March 1974 plantings produced over 35 tons/ha of marketable roots. Its peak yield was obtained from the November 1973 planting and the lowest production (28.1 tons/ha) from the January 1974 planting. This cultivar is recommended for year-round plantings.

TABLE 3.-Yield of the yellow-fleshed sweetpotato cultivars planted at six different dates

\begin{tabular}{lrlllll}
\hline \multirow{2}{*}{ Cultivars } & \multicolumn{6}{c}{ Yields at indicated date of planting (tons/ha) ${ }^{\mathrm{1}}$} \\
\cline { 2 - 6 } \cline { 3 - 6 } & July/73 & Sept./73 & Nov./73 & Jan./74 & Mar./74 & May/74 \\
\hline Gem & $35.2 \mathrm{a}$ & $33.0 \mathrm{a}$ & $38.7 \mathrm{ab}$ & $28.1 \mathrm{a}$ & $35.9 \mathrm{a}$ & $33.5 \mathrm{a}$ \\
Cobre & $8.2 \mathrm{~b}$ & $10.3 \mathrm{~b}$ & $32.2 \mathrm{c}$ & $22.7 \mathrm{a}$ & $11.5 \mathrm{~b}$ & $10.0 \mathrm{~b}$ \\
L $963-3$ & $25.3 \mathrm{c}$ & $28.6 \mathrm{a}$ & $34.2 \mathrm{ac}$ & $29.2 \mathrm{a}$ & $22.4 \mathrm{c}$ & $21.4 \mathrm{c}$ \\
R $59-36$ & $5.1 \mathrm{~b}$ & $23.3 \mathrm{c}$ & $40.7 \mathrm{ab}$ & $25.9 \mathrm{a}$ & $12.2 \mathrm{~b}$ & $3.4 \mathrm{~d}$ \\
\hline
\end{tabular}

\footnotetext{
${ }^{1}$ Means in any column followed by the same letter are not significantly different at the 0.05 probability level.
}

Cobre. Peak yield of the Cobre cultivar (32.2 tons/ha) was obtained from the November 1973 planting. When planted in July and September 1973, it produced as low as when planted in March and May 1974. However, yields increased when planted in January 1974. Thus, it would be more profitable to plant this cultivar during the November-January season than during other periods of the year.

L 963-3. This cultivar was a high yielder the year-round. It produced good yields when planted in July and September 1973 or when planted in January and March 1974. Its peak yield (34.2 tons/ha) was obtained from the November planting and the lowest yield from the May 1974 planting.

R 59-36. Peak yield of this cultivar (40.7 tons/ha) was obtained from the November 1973 planting. Yield was low when planted in July 1973, March 1974, and May 1974. It was a high yielder, however, when planted from September 1973 to January 1974.

In general, the best yields were obtained from the November 1973 
plantings, irrespective of cultivars, and the lowest yields were obtained from the July 1973 plantings. The September 1973 and the January 1974 plantings yielded fairly good crops, however.

\section{Evaluation by Crops}

July 1973 Planting. Cultivar Gem produced significantly higher yields than Cobre, L 963-3, and R 59-36 in the July 1973 planting. Yields of cultivar L 963-3 were significantly higher than those of Cobre and R 59-36, but there were no significant differences between the yields of the latter two cultivars.

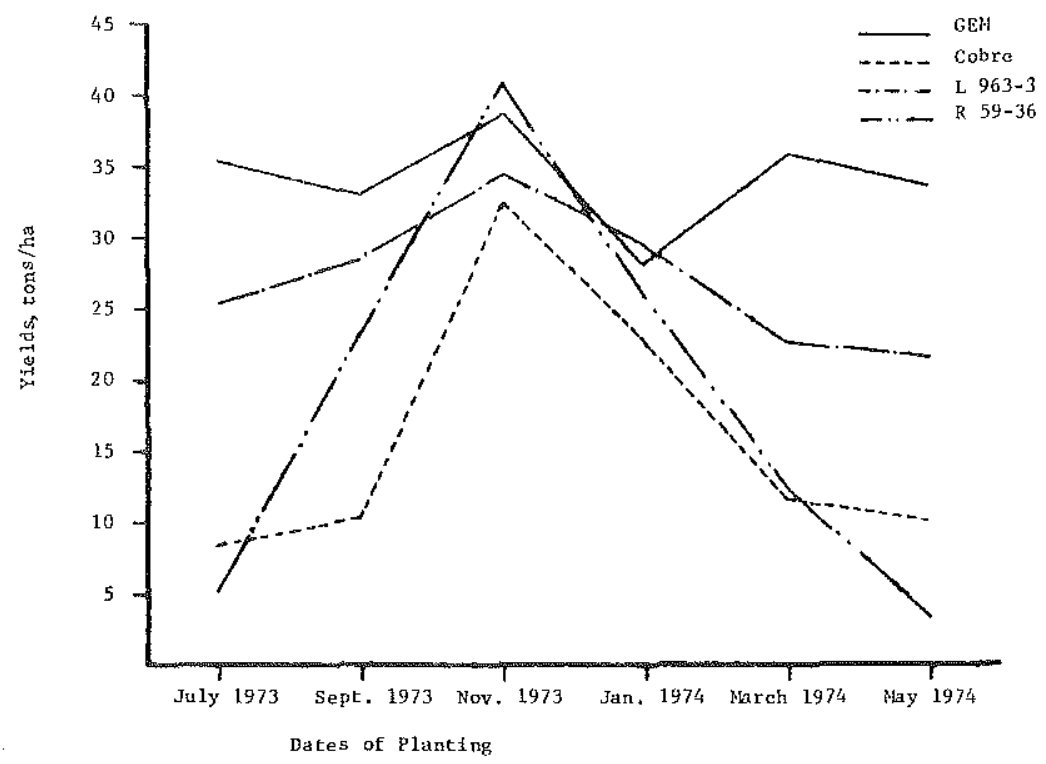

FIG. 2. Relationship between dates of planting and yield of yellow-fleshed sweetpotatoes.

September 1973 Planting. Yields from cultivar Gem and L 963-3 in the September 1973 plantings did not differ significantly. Both cultivars outyielded Cobre and R 59-36, but yields from R 59-36 were higher than those from Cobre.

November 1973 Planting. Yields from cultivars Gem, L 963-3, and R 59-36, did not differ significantly in the November planting, but both cultivars produced higher yields than Cobre. There were no significant differences between yields of L 963-3 and Cobre.

January 1974 Planting. The mean yield of cultivars Gem, Cobre, L 963-3, and R 59-36 in the January 1974 plantings did not differ significantly. 
March 1974 Planting. Cultivar Gem outyielded L 963-3, Cobre, and R 59-36 in the March 1974 planting. The L 963-3 cultivar produced significantly higher yields than Cobre and $\mathrm{R}$ 59-36. There were no significant differences between the mean yields of the latter two cultivars, however.

May 1974 Planting. Cultivar Gem out-yielded Cobre, L 963-3, and $R$ 59-36 at the $1 \%$ probability level when planted in May 1974. There were significant differences between mean yields of Cobre, L 963-3, and R 59-36.

All Crops. The analysis of the pooled yield data from the six crops shows that cultivars Gem, Cobre, L 963-3, and R 59-36 yielded 34.1, 15.8, 26.9 , and 18.5 tons/ha, respectively. The mean differences between cultivars were significant.

\section{RESUMEN}

Con el fin de determinar el efecto de la época de siembra de la batata se realizaron varios ensayos en un suelo Coto (Oxisol) en la Subestación de Isabela. Se efectuaron seis siembras bimestrales. Las siembras se iniciaron en julio de 1973 y se terminaron en mayo de 1974. La cosecha se efectuó cinco meses después de la siembra. Los cultivares blancos inclúfdos en las pruebas fueron: Miguela, Chardón, Mina, Ponceña y Blanquita. Los de tipo mameya fueron: Gem, Cobre, L 963-3 y $R$ 59-36. Los ensayos se llevaron a cabo separadamente aunque en campos adyacentes. La parcela experimental consistió de cuatro hileras a $1.1 \mathrm{~m}$. de separación y $5.5 \mathrm{~m}$. de largo. Los tratamientos se distribuyeron en un diseño de bloques al azar con seis replicaciones.

El rendimiento óptimo de batatas blancas y mameyas se obtuvo de la siembra efectuada en noviembre de 1973. Los de las siembras efectuadas en septiembre de 1973 y en enero de 1974 fueron relativamente buenos. En general, las siembras efectuadas durante marzo o mayo de 1974 fueron las que menos produjeron.

Entre los cultivares blancos, Miguela y Mina, fueron en general, productores consistentes en todas las épocas. Los cultivares Ponceña y Blanquita produjeron el máximo en la siembra de noviembre de 1973; sin embargo; fueron pobres productores en las siembras efectuadas en julio de 1973 y en mayo de 1974. El cultivar Chardón fue un pobre productor en todas las épocas de siembra.

Entre los cultivares de tipo mameya, Gem fue el mejor productor en todas las épocas de siembra. Este cultivar parece no ser afectado por el largo del día. Sin embargo, el cultivar $\mathrm{R}$ 59-36 demostró ser altamente fotoperiódico. Se obtuvo el mejor rendimiento de este cultivar en la siembra efectuada en noviembre y los inferiores en las efectuadas en julio de 1973 o mayo de 1974. El cultivar L 963-3, aunque no tan buen productor como el cultivar Gem, sí produjo buenas cosechas en todas las épocas de siembra. El cultivar Cobre fue aparentemente afectado por el largo del día, aunque en menor grado que el cultivar R 59-36. 